\title{
Suicide, Terrorism and the Dilemma of Global Peace
}

\author{
Tem Okolocha Alabi \\ Department of Political Science / International Relations, School of Postgraduate Studies and Research, \\ Igbinedion University, Okada, Edo State, Nigeria
}

\begin{abstract}
Suicide terrorism is a violent attack designed to kill others where the death of the attacker is a necessary part of the action. It is through the death of the suicide bomber that the mission, the killing of others or destruction of a target, is accomplished.

I have often wondered in my quiet moment what inspires people to kill themselves, why these people are so committed to their cause to the point of death and also wondered if there can ever be a change in this cause positively considering the very negative impact on world peace.

Suicide terrorism has emerged as a very powerful weapon over the last several years, with 9/11, car bombings in Iraq, in the West Bank, in Sri Lanka, in northern Nigeria and elsewhere. It has captivated the public and has infiltrated our national consciousness.

This paper tends to find out why people would strap a bomb on and blow themselves up, or get in a car that has a bomb and run it into something, why suicide terrorism has emerged in the last few decades as such a potent weapon, and most importantly how this tragic phenomenon crept into Nigeria and has taken center stage in the area of terrorism. Certain reasons were derived from the study, one explanation revolves around individual-level factors-individuals who had grievances against a government or group who sought to demonstrate their anger or fury through a suicide attack. Other explanations postulated psychological weaknesses while others seem to suggest there is a strong link between economic weakness and suicide terrorism, either at the national or individual level. In Nigeria, a popular explanation has to do with the combination of religion and globalization.

The paper concludes that suicide terrorism is now a regular tool of sectarian violence. It is therefore unlikely that it would go away. Therefore, we should study suicide terrorism in a serious fashion, looking at the big picture and the key variables that explain behavior, rather than in an emotional manner.
\end{abstract}

Keywords: Terrorism, Suicide, Religion, Globalization.

\section{Introduction}

To each age its challenges, could we ever find a global peace? Why do we have so much violence and hatred globally? What are the grievances that motivate these acts? What are the sociopolitical factors that sustain their existence? What are the rationales behind modern religion-based terrorism? What has led to the current outbreak of suicide terrorism globally? Have conditions somehow worsened in recent years?

Although terrorism is not a new phenomenon, the nature and character of terrorism is changing because new adversaries with very different rationales and motivations have emerged to challenge the conventional wisdom on terrorist and terrorism. We are therefore at the dawn of new era of terrorist violence which is more even bloodier and more destructive than before.

Terrorist have become increasingly attracted to suicide attacks because of their unique tactical advantages compared to those of more conventional terrorists operation, suicide attack is less complicated and compromising than other terrorist operations, since no escape plan is needed: if the attack is successful, there is no assailant to capture and interrogate. They are devastatingly effective and relatively inexpensive and generally easier to execute where the perpetrator's own death is the essential requirement and terrorists themselves have pointed out that it is easy and costs only their lives.(Pape 2003 ).

According to Hoffman(2006) "Rather than the wild-eyed fanatics or crazed killers that we have been conditioned to expect, many are in fact highly articulate and extremely thoughtful individuals for whom terrorism is (or was) an entirely rational choice, often reluctantly embraced and then only after considerable reflection and debate. So in targeting potential recruits for suicide terrorism, it must be understood that terrorist attacks will not be prevented by trying to profile terrorists. They are not sufficiently different from everyone else 
This paper looks at how apparently 'normal' people have nonetheless deliberately chosen a path of bloodshed and destruction and how these activities have affected the global peace, also highlighted different causes and reasons as to why females choose to perform these deadly actions, the moral implication of suicide terrorism with particular reference to Boko haram.

Some of the reasons attributed to these deadly actsare beliefs and ideologies; they can also be motivated by political and/or historical contexts to take action against their enemies. Religion as encouraged by the Muslims is also implicated as playing prominent roles in framing popular attitudes towards suicide operations and encouraging their followers to carry out acts of self sacrifice on behalf of their community, suicide terrorism thus becomes ultimate expression of selflessness and altruism and the perpetrators of this violence are thus accorded a special status and are revered.Theattacks are justified for seeking for martyrdom, hurting the enemy, encouraging Muslims and weakening the spirit of the enemy (Hoffman, 2006). The popularity and the growth of self-proclaimed religious factions also opened the way for the misuse of religion for instrumental gains.(Hansen, 2013).

It was observed that most suicide bombers do not conform to the typical suicide personality; they are educated, not desperately poor, and not simple minded or depressed. They are sometimes middle class and held paying jobs.

The paper concludes that Suicide terrorism is adopted around the world because they are shocking, deadly, cost effective, secure and very difficult to stop, only two basic requirements: a willingness to kill and a willingness to die and most importantly, Civilization rise and fall in proportion to how we respond to new Challenges, Nigerian government needs to find a creative way of meeting this challenge.

\section{Defining Suicide Terrorism}

A suicide attack is a violent attack in which the attacker expects to die in the process;Pedahzur(2005) defined suicide terrorism as "violent actions perpetrated by people who are aware that the odds they will return alive are close to zero." But most writers argue that the odds of survival are not close to zero but required to be zero, because the perpetrator's ensured death is a precondition for the success of his mission.

Hoffman(2003) also describes the characteristics of suicide bombing, as "universal", inexpensive and effective. They are less complicated and compromising than other kinds of terrorist operations. They guarantee media coverage. The suicide terrorist is the ultimate smart bomb. Perhaps most important, coldly efficient bombings tear at the fabric of trust that holds societies together."

The meaning and nature of suicide in a suicide bombing are strikingly different from ordinary suicide. Suicide bombing falls into the category of altruistic suicidal actions that involve valuing one's life as less worthy than that of the group's honor, religion, or some other collective interest. (Hassan2009).

Suicide terrorism in general is a violent attack designed to kill others where the death of the attacker is a necessary part of the action. Unlike suicide mission where the men get together and are sent on a mission that they know they are probably going to die, but it is not their deaths that cause the mission to succeed but in a suicide attack it is through your death that your mission, the killing of others or destruction of a target, is accomplished.

\section{History of Suicide Terrorism}

The concept of self-sacrifice has long been a part of war, but the idea of suicide bombing as a tool of stateless terrorists was not, until 1983 when Shiite militants blew up the U.S. Marine barracks in Lebanon, that it became "tool of modern terrorist warfare.(Feldman,2006)

Lebanon saw the first bombing, but it was the Tamil Tigers (Liberation Tigers of Tamil Eelam) in Sri Lanka who perfected the tactic and inspired its use elsewhere. Their Black Tiger unit committed 82 suicide attacks from 1987 to 2009, killing 961 peopleincluding former Indian Prime Minister Rajiv Gandhi and the president of Sri Lanka, RanasinghePremadasa and Al-Qaeda carried out its first suicide attack in the mid-1990s.

Recently, Islamic suicide bombing has taken center stage. "The very idea that Muslims might blow themselves up for God was unheard of before 1983, and it was not until the early 1990s that anyone anywhere 
had tried to justify killing innocent Muslims who were not on a battlefield. Since then, the vocabulary of martyrdom and sacrifice, videotaped pre-confession of faith by attackers have become part of Islamic cultural consciousness, instantly recognizable to Muslims while the tactic has spread through the Muslim world with astonishing speed and on a surprising course (Feldman 2006)

\section{Suicide Terrorism In Nigeria And The Emergence of Boko Haram}

Violent confrontation have escalated in north- eastern Nigeria since the mid of 2000s, between federal forces and the group popularly known as Boko Haram. Book Haram, in Hausa language means "Western education is sinful" the group has its goal to Islamize Nigeria, to occupy northern and central states by ensuring that Nigeria is a failed state with no federal authority to stop its jihadist's march to western target- cities in Europe and the United States. (Simons 2015). The set has become a fashionable topic of research as well as international issue but a difficult task, as researchers have very limited access to first hand information as they find it almost impossible to conduct field work in north-eastern Nigeria where their security cannot be guaranteed.

What today is known as Boko Haram started as atiny group of people who withdrew from the urban landscape of Maiduguri to rural Kanama in the Yunusari local government area of Yobe state to in north-eastern Nigeria in December 2003, they referred to themselves as 'Nigerian Taleban(Mohammed, 2015). This site was carefully chosen for its remoteness and defensibility and members of this group were mostly young people in their twenties which included females assigned domestic chores. Some of them were children of notable public figures including anephew of the then serving governor of Yobe state, a son of the secretary to Borno state and five children of local wealthy contractor(Mohammed 2015).

Although the movement has been incubating in northern Nigeria, its transformation into an armed violent group can be traced to events leading to the 2003 elections in Nigeria. With the exit of the original founder of the sect, AbubakarLawan, on further studies in Saudi Arabia, a committee of clerics appointed Mohammed Yusuf as their leader in 2002. Afterwards, Mohammed Yusuf ousted the clerics that who appointed him, on allegation of corruption and failure to properly interpret the teaching of the Quaran. (Onuoha, 2015).

Yusuf was very charismatic and his preaching endeared him to many young Muslims and even attracted many from beyond Yobe state to the neighboring countries like Niger and Chad. He redefined the doctrine of the set around an ideology that abhors western education and the tenets of western science. Though he preached a simple life, he enjoyed western luxuries, the sect activities became worrisome when students from tertiary institutions who constituted the sect's membership withdrew from school and tore up their certificates, and they disassociated from society and became more indoctrinated to anti-secular ideologies.

Mohammeed successfully changed the attitude of his followers and imposed Arabic as the only language of communication amongst members. This move attracted followers from the unemployed "Almajiri" youth who find comfort in the camp welfare programs. Preaching against the evil of elitism and corruption of politicians supposed enemies of the growth of Islam; this group thrived and prospered with lots of local supports and patronage.( Adeniji,2014).

Following the death of Yusuf who was killed by security operatives and the mass killing and arrest of many of his member, Yusuf hard-line top deputy became the sect's new spiritual leader, the sect has continued to perpetrate acts of violence on diverse targets and have resulted to a new tactics including the adoption of suicide terrorism. The method of suicide terrorism adopted by the sect is suicide bombing, which refers to any politically or ideologically motivated violent attack perpetrated by a self- aware individual(s) who actively and purposely causes his or her own death through blowing himself or herself up along with the chosen target.(Onuoha,2015).

Professionalism and the radicalization of the sect now pose significant threats even beyond Nigeria. In the view of Onuoha, the audacity of Boko Haram reflects the weakness of the Nigeria state and its ability to build government legitimacy, to deliver public goods, to strengthen moderate Islam and to implement a robust program on countering ideological support for extremism and terrorism.

The US secretary of state, Kerry issued a \$7m bounty for the capture of Abu Shekau, Boko Haram's blood thirsty leader. But aside from the proven ineffectual nature of this approach to the classic decade-long pursuit of bin Landen, this match com strategy for combating terrorism is clearly a long shot in the dark. The US needs to 
know from retail piece- meal designation of favorite terrorists to wholesale designation of the entire organization. Half hearted and half baked measures are exactly how a Nigerian suicide bomber got on a flight to Detroit with a bomb in his underpants on Christmas even though his father had walked into American embassy and warned them about his son.(House of Representatives, Committee on Foreign Affairs, 2013)

\section{Boko Haram's Use of Women as Suicide Bombers}

Suicide bombers are normally viewed as male political radicals, but since the 1960s female suicide attacks have been on the rise. There are many organizations that recently started using women as tools in their attacks, since they are normally viewed as less of a threat than their male counterparts. This includes women having the element of surprise, a hesitancy to search females, increased publicity for female suicide bombing attacks, and the female stereotype as non-violent.

Lately, female suicide bombers have been observed in many predominantly nationalist conflicts by variety of organizations against both military and civilian targets, having been given permission by the religious leader of Hamas to participate in suicide attacks. There are terrorist organizations that trained many female suicide bombers since their uprising as political weapons. Terrorist organizations recruit and motivate women to participate in suicide attacks, using traditional attitudes of honor and feminine harmlessness and vulnerability among target populations to insert attackers were they can cause a maximum of death and destruction.Bombs have been disguised as a pregnant belly, avoiding invasive searches, seen as taboo. By stumbling or calling out in distress more victims may be drawn to the explosion. These women have proven to be more deadly with higher success rates with more casualties and deaths than their male counterparts. The woman bomber carriers are not permitted to hold and control the detonator, which are still held by the men in charge. Until recently, attacks of women bombers were considered more newsworthy because of the "unladylike" behavior of their perpetrator.(O’Rourke)

Of all the mysteries surrounding Boko Haram, the use of women and girls as suicide bombers is among the most vexing. The group sent three girls to a government-run camp in Nigeria that was supposed to be a haven for people who had been chased from their homes under threat or attack by the group. Those three at the camp in Dikwa are among an increasing deployment of women and girls who have served as suicide bombers in recent Boko Haram attacks. The girls posed as refugees from the violence at night and two blew themselves up in the morning, killing 58 people and wounding 78. The third girl did not detonate her device. The authorities said she had recognized her parents and siblings among those seeking shelter at the camp and had surrendered.(Schmitt 2016).

\section{Global Peace at a Dilemma}

In many parts of the world, suicide terrorism has taken center stage, fears and anxieties has become a redefined normality, Boko Haram was once a Nigerian issue but today, it is a global issue, what this means is that states in the international system are interwoven so much so that what affects one state invariably affects another state or group of states, therefore states would increasingly become more concerned with the wellbeing of other states and this is why it is sometimes difficult to differentiate domestic problems from the external one.

We have reached a level where people are afraid about riding the bus, going to a mall and sitting for long at your favorite café. Nowhere seems safe as it now very easy for a person to wake up in the morning and go off and commit suicide. Terrorist groups have a strategy to shrink to nothing the areas in which people move freely and incidentally, they are guaranteed media coverage and sometimes, terrorist are more interested in publicity than in killing. It is thus embraced.

According to Pape (2003) the majority of suicide bombers came from the educated middle classes. (HumamBalawi who perpetrated the Camp Chapman attackin Afghanistan in 2010, was a medical doctor.) There are doubts on the widely held belief that terrorism stems from poverty, finding instead that terrorist violence (not just suicide terrorism) is related to a nation's level of political freedom, with countries in some intermediate range of political freedom more prone to terrorism than countries with high levels of political freedom or countries with highly authoritarian regimes. When governments are weak, political instability is elevated, so conditions are favorable for the appearance of terrorism, this is why it is usually said that African countries are prone to violence. 
In the United States since 9/11 there has been an array of new, often previously inconceivable security measures in airports and other transportation hubs, hotels and office buildings, sports stadiums and concert halls. Although some are more noticeable and perhaps more inconvenient than others, the fact remains that they have redefined our own sense of normality. They are accepted because we feel more vulnerable than before. With every new threat to international security we become more willing to live with stringent precautions and reflexive, almost unconscious wariness. With every new threat, that is, our everyday life becomes more like Israel's. (Pape 2003). Suicide terrorism even makes adjustment to reduce damage more difficult than military coercion or economic sanctions.

The early years of suicide terrorism were a simpler time,Suicide bombers were easier to spot then. They tended to carry their bombs in nylon backpacks or duffel bags rather than in belts or vests concealed beneath their clothing, as they do now. They were also typically male, aged seventeen to twenty-three, and unmarried. Today, though, suicide bombers are middle-aged and young, married and unmarried, and some of them have children. Some of them, too, are women, and word has it that even children are being trained for martyrdom but there is no clear profile anymore. Children are paying for this insurgency in multiple ways, children are been selected by Boko Haram in Nigeria for suicide missions. The group had first introduced body-borne improvised explosive devices in 2011 at a time when many would have sworn that the concept of suicide attack was foreign and completely un-Nigerian. (Comolli, 2015).

These organizations terrorize people in their urban centers or even travelers, all such attacks constitute a corruption of the earth and peace becomes elusive and since a successful suicide bomber cannot be targeted, the response is often a targeting of those believed to have sent the bomber.

Globally, Citizens have a fundamental expectation that their government and its military and security forces will protect and defend them and the right to good governance is a fundamental right in the international court of law. Soldiers are expected to die, if necessary, in order to discharge this responsibility. Suicide terrorism does not change a nation's willingness to trade high interests for high costs but suicide attacks can overcome a country's efforts to mitigate civilian costs. Accordingly, suicide terrorism may marginally increase the punishment that is inflicted and so make target nations somewhat morelikely to surrender modest goals, but it is unlikely to compel states to abandon important interests relatedto the physical security or national wealth of the state. (Pape 2003).

Although Since the 9/11 attacks, Western nations have diverted massive resources towards stopping similar actions, as well as tightening up borders, and military actions against various countries believed to have been involved with terrorism, the number of recruits are increasing and so is their willingness to carry out suicide bombings.

Recent years have also seen an increase in religious-ideological terrorism whose manipulation of supportive civilian populations so as to wield violence against other civilians whom they regard as infidels represents a "perfecting of modern terrorist strategies. (Ganor,2015).So, suicide bombing has both religious and sociopolitical motivations, those who cite religious factors as an important influence note that religion provides the framework because the bombers believe they are acting in the name of Islam and will be rewarded as martyrs. Since martyrdom is seen as a step towards paradise, those who commit suicide while discarding their community from a common enemy believe that they will reach an ultimate salvation after they die. Some radical scholars are quoted as promising various heavenly rewards, such as 70 virgins as wives, to Muslims who die as martyrs, (specifically as suicide attackers (Feldner 2016) opined thatthe death announcements of martyrs in the Palestinian press often take the form of wedding, not funeral, announcements. 'Blessings will be accepted immediately after the burial and until $10 \mathrm{p} . \mathrm{m}$. at the home of the martyr's uncle. Other allegedrewards for those dying in jihad are feeling no pain from the cause of their death, being cleansed of all sin and brought directly to paradise, not having to wait for the Day of Judgment.

The connection of the high percentage of suicide attacks executed by Islamist groups with the religion of Islam is disputed. Specifically, scholars, researchers, and others, disagree over whether Islam forbids suicide in the process of attacking enemies or the killing of civilians, they have posited that suicide attacks are a clear violation of classical Islamic law and characterized such attacks against civilians as murderous and sinful. According to Lewis(1993), the emergence of the now widespread terrorism practice of suicide bombing is a 
development of the 20th century. It has no antecedents in Islamic history, and no justification in terms of Islamic theology, law, or tradition.

Tahir-ul-Qadri (2011) directly disputed the rationale of Islamists, arguing among other things that the indiscriminately killing of both Muslims and non-Muslims is unlawful, and brings the Muslim into disrepute, no matter how lofty the killers intentions.He states that terrorism "has no place in Islamic teaching, and no justification can be provided to it...good intention cannot justify a wrong and forbidden act".

Overall, the trend is definitively in the direction of Muslim-on-Muslim violence. Suicide bombing has become the archetype of Muslim violence - not just to Westerners but also to Muslims themselves.

\section{Conclusion}

Understanding the terrorist organization's logic is more important than understanding individual motivations in explaining suicide attacks. Suicide bombings have high symbolic value because the willingness of the perpetrators to die signals high resolve and dedication to their cause. They serve as symbols of a just struggle, galvanize popular support, generate financial support for the organization and become a source of new recruits for future suicide missions.

We should also focus on suicide terrorism as an example of the diffusion of innovations. They came back with what were effectively operational blueprints for how to plan and executive suicide attacks, especially against hard targets like embassies. Hezbollah was really thought of as an innovator, the first mover. his story shows the spread of the idea to the primary adopter of suicide terrorism-Al Qaeda. The subsequent history of suicide terrorism is best thought about as a diffusion process (Horowitz 2008).

Contrary to the popular image that suicide terrorism is an outcome of irrational religious fanaticism, suicide bombing attacks are resolutely a politically-motivated phenomenon. The main reason that suicide terrorism is growing isthat terrorists have learned that it works. Statesthat face persistent suicide terrorism should recognizethat neither offensive military action nor concessionsalone are likely to do much good and should invest significantresources in border defenses and other meansof homeland security.

Just like suicide terrorism, to succeed with campaigns against suicide bombing, we need

- willing individuals,

- organizations to train and use them, and

- A society willing to accept this fight in the name of a greater good.

\section{References}

[1] Scott."The Moral Logic and Growth of Suicide Terrorism (figure 1, pg. 128)" (PDF). sitemaker.umich.edu. Retrieved march 1, 2016.

[2] Lewis (1993) Islam and the West. Penguin Books, England.

[3] M. Adeniji (2014) Boko Haram, Designing effective Counter-Terrorism Programme.

[4] Schmitt (2016) Boko Haram Trend: Use of Female Bombers. February 12, 2016, on page A9 of the New York edition.Assessed on the 10/3/16.

[5] H. Riaz( 2009)."What Motivates the Suicide Bombers?".Yale Global.Yale Center for the Study of Globalization. Retrieved march 2, 2016.

[6] Hoffman, Bruce (June 2003)."The Logic of Suicide Terrorism".The Atlantic.Retrieved $4{ }^{\mathrm{TH}}$ march 2016.

[7] House of Representatives,Committee on Foreign Affairs(2013). The continuing threat of Boko Haram. Amazon.co.uk,Ltd. Great Britain.

[8] Kay, Jonathan( 2005). "Dying to Win: The Strategic Logic of Suicide Terrorism".Islam Daily. Retrieved 5 march 2016

[9] M. Tahir-Ul-Qudri (2011) Fatua on terrorism and suicide bombing, https://ww.facebook.com/fatwaonterrorism

[10] Michael Horowitz (2012), The History and Future of Suicide Terrorism.Foreign policy research institute, Philadelphia.

[11] Noah Feldman (October 29, 2006). "Islam, Terror, and the Second Nuclear Age".New York Times.

[12] O'Rourke, L.A. (2009). "What Special About Female Suicide Terrorism?".Security Studies 18: 681-718. doi:10.1080/09636410903369084.

[13] A.Pedahzur, (2005) Suicide Terrorism, Cambridge University press..

[14]R Hassan (2009) What Motivates the Suicide Bombers?Yale Center for the Study of Globalization.Retrieved on the $10 / 3 / 16$.

[15] R. Simons, (2015) Boko Haram \& the Agenda of A failed Nigerian State. Amazon.co.uk.ltd, Great Britain 
[16] R.A. Pape(2003)The Strategic Logic of Suicide Terrorism American Political Science Review Vol. 97. [17] Retrieved on the 10/3/16

[18] R.A Pape(2005).Dying to Win.Random House.ISBN 1-4000-6317-5. New York:

[19] S. Atran, The Moral Logic and Growth of Suicide Terrorism (pp. 131, 133); sitemaker.umich.edu; assessed feb 11, 2016.

[20] V.Comolli, (2015) Boko Haram, C.Hurst \&Co.(publishers) Ltd. England.

[21] www.memri.org, Assessed on the 10/3/16 